\title{
2
}

\section{MAKING KNOWLEDGE FROM BELOW}

\author{
Senna Middelveld, Harro Maat, and Phil Macnaghten
}

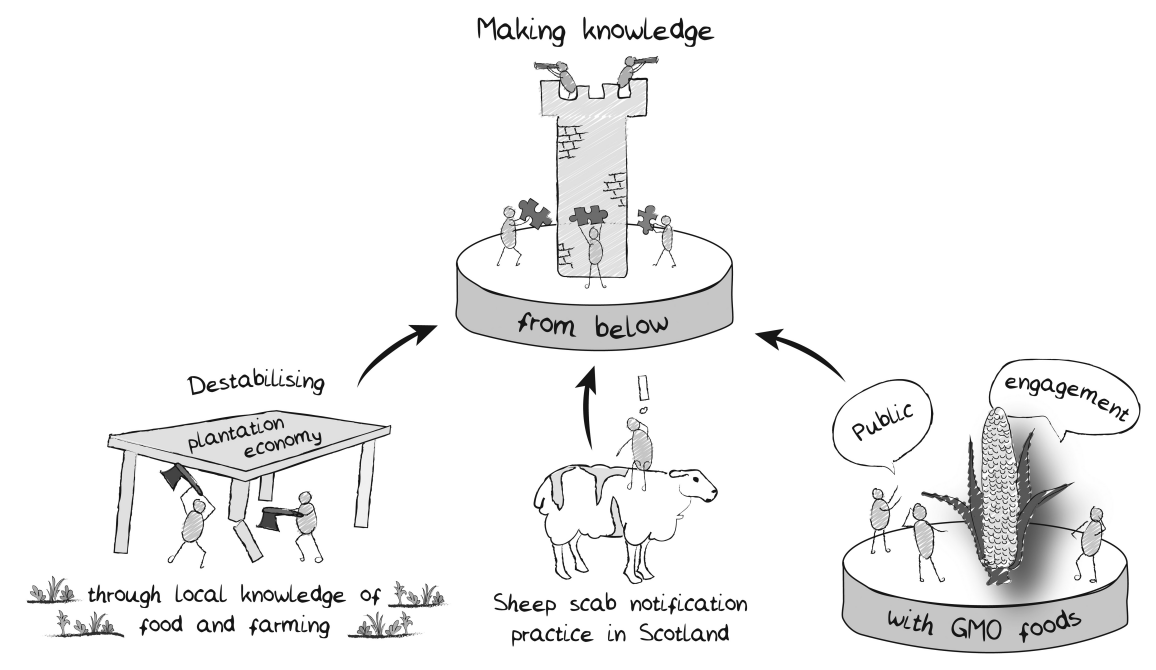

\section{Introduction}

Several established scholarly domains and academic disciplines originate from practices in which locally vernacular knowledge and established techniques once prevailed. Known examples are medicine and agricultural science. Since at least the dawn of the Modern age, institutional scientific knowledge making practices have become the dominant source for practical application. Yet far from being a value free enterprise, practices of scientific knowledge making have contributed to thin simplifications of nature and society, conducive to prevailing and utilitarian models of social order. The domination of institutionalised scientific 
knowledge over other forms of knowledge implies not only that formal scientific knowledge is considered somehow superior to local vernacular knowledge, but also that its application through science-led innovation conjoined with rational planning is the motor of prosperity and social progress. Perhaps not surprisingly, this domination by science has been resisted by civil society and critical social scientists who have sought recognition and engagement with local and indigenous perspectives.

In this chapter we contribute to an appraisal of institutionalised scientific knowledge making practices through an assessment of what we call 'knowledge from below' and its potential for social innovation (see also Carenzo, 2020 for a wider theorisation of initiatives that usually remain below the radar). The 'below' refers to people's daily practices and experiences in a broad sense, and as such a prominent domain for the 'life sciences' both as a source of empirical data and as an 'application environment' for science-based interventions. However, in normal scientific procedures information from below is often stripped from its social and epistemological situatedness. For example, what people prefer to eat, what crops and animals farmers hold on their fields or the birds we see when looking at our backdoor gardens all end up as data points in spreadsheets and computer files, processed and interpreted from the scientific models about human behaviour, farming systems, or ecology. Knowledge 'from below' is therefore not used to indicate that local knowledge or the people having it are below. Instead, we use it to emphasise that these knowledges come from below, illustrating a resistance from below against institutionally embedded knowledge 'from above.'

More than arguing for the need to critique scientific knowledge, this chapter highlights ways in which novel forms of productive engagement with local, plural, and deliberative ways of knowing opens up new and potentially more inclusive forms of knowledge production. The argument of the chapter is inspired by a co-production model and approach in which the spheres of science and social order are viewed as mutually constitutive. Developed by Sheila Jasanoff and colleagues and building on science and technology studies (STS) scholarship, the co-production concept has proven very helpful to unveil how the incontrovertible facts produced by science 'are designed to persuade publics [in ways that] are co-produced along with the forms of politics that people desire and practice' (Jasanoff and Simmet, 2017, p. 752). There are two broad implications that derive from this approach.

First, if science and social order are co-produced, then it becomes incumbent to examine precisely the relationship in practice between scientific knowledge production and social order as evinced in particular sites. STS scholars have taken up this task for a wide variety of cases, identifying both the values out of which science is conducted-including the interests it serves-as well as the ways in which these configurations can, over time, contribute to the formation of new meanings of life, citizenship, and politics, or what can more generally be dubbed 'social ordering' (Jasanoff, 2004; Rose, 2006). Second, if it is acknowledged that science and social order are co-produced, the question arises what values 
underpin the scientific knowledge production system (and its associated cultures), and to what extent these align with articulations of broader societal values and visions of the social good. Indeed, to what extent have the values and priorities tacitly embedded in scientific innovation been subjected to democratic negotiation and reflection? Or, perhaps more worryingly, to what extent are dominant scientific values reflective of those of incumbent interests that may be, perhaps unwittingly, closing down possibilities for different scientific pathways linked to alternative visions of the social good (Stirling, 2008)?

This chapter takes up the challenging insights and questions raised by the coproduction concept by exploring novel forms of productive engagement with local, plural, and deliberative ways of knowing, Moreover, we introduce additional concepts, endorsing and extending the co-production argument, and furthering a critical examination of the way 'knowledge from below' contributes to alternative social orderings.

In the first case, we offer a historical perspective by reassessing forms of resistance against Caribbean slave-based plantation economies with productivist social organisation. For plantation owners and estate managers, nature and slaves were subjects for exploitation, and both served to extract financial profit. Resistance and maronnage contested the plantation order successfully because subsistence farming was a viable alternative reflecting a counter understanding and ordering of nature and human relations. Theoretically, and drawing on the writings of Durkheim and Mauss, we view knowledge from below as embodied interaction with natural environments from which particular social orderings emerge.

The second case draws on ethnographic fieldwork conducted in Scotland with sheep farmers and veterinarians. We analyse how the Scottish government's decision to remake sheep scab a notifiable disease, based on expert scientific knowledge, led to resistance and alternative ways of knowing and practising the disease. In this case, knowledge from below is embodied and located in Scottish farmers' and veterinarians' knowledge practices and experience with sheep and sheep scab. From an STS tradition, we draw on the ideas of Haraway (1988) about situated knowledges and on skilled visions, a notion developed by Grasseni (2007) as a way of attending to local knowledge practices at the level of epistemology and ontology.

In the third case, we show how a public engagement research project on public responses to genetically modified foods was used to contest a dominant science policy framing that had viewed negative public attitudes as based on emotion and dogma. Designing and developing a new kind of collective-using deliberative focus groups (Macnaghten, 2021; see also Chapter 12 in this volume) in which lay publics are empowered to negotiate the meanings of issues endogenously - the research brought to the fore questions of trust, agency, the 'reasonableness' of public concerns, and the need for new policy architectures that embrace 'beyond risk' dimensions. In this case, knowledge from below emerges from lay publics during focus group discussions. Their knowledge about emerging technologies is often marginalised and overlooked, especially 
when compared with knowledge and knowledge frames produced by the scientific community developing the technology, knowledge that is institutionally legitimated by regulators and industry.

\section{Case 1. Destabilising the plantation economy through local knowledge of food and farming}

The colonisation of territories in Asia, Africa, and the Americas involved the forceful imposition of the European social order on other societies. Centuries of colonisation, competition, and maritime warfare made armed force the central means by which access to natural resources and produce was secured. The ferocious commodification extended to human beings, most prevalent and systematic in the transatlantic slave trade (Eltis and Richardson, 2010). The majority of the slaves were sold to European plantation owners on the Caribbean islands and on mainland South America. Science was called in to justify the plantation system as an 'efficient' agricultural system, most prominently towards the end of the 19th century, when agricultural research explored new technologies to further increase the productivity of soils, crops, and plantation workers (Ross, 2014). During the same period, slave-based labour on plantations in the Caribbean came to be replaced by contract labour, recruited primarily from India and other Asian countries. Despite European dominance, the social order of the plantation system was continuously challenged by revolts, resistance, and escape by the resident labour force. The various forms of resistance, it is argued here, were rooted in the co-production of knowledge from below and a social order based on subsistence farming.

Two notions from the work of Marcel Mauss are helpful to understand the ways in which knowledge from below sustains an alternative model of social order that underpins the practices of resistance of plantation workers. Mauss used the method of his uncle Emile Durkheim to investigate how social structures and moral order emerge through specific and formational social phenomena. One such phenomenon is the human capacity to use technology. ${ }^{1}$ Mauss's interpretation of technology is well summarised by the title of his best-known essay on the topic: Techniques of the Body. He observed substantial variation in the way people from different societies employ and develop bodily techniques for numerous simple tasks. This variation, Mauss argued, is cultural in that it is transferred from parent to child over many generations, resulting in traditions and routines. The principle - that knowledge transfer takes place through bodily techniques in social interaction — can be extended to the use of tools, machines, and technical systems as societies connect, expand, and innovate. Exchange of techniques and knowledge about techniques between cultures are key drivers of social innovation, to the effect that 'societies, like techniques and like the [person] who practices them, are made out of synthesis rather than distillation, that their lack of "purity" is their source of strength, that métissage or créolisation is not their worst nightmare but their salutary fate' (Schlanger, 2006, p. 28; see also Tsing, 2015). 
A second insight from Mauss is from his influential essay on The Gift, where he theorises on principles of exchange based on a study of symbolic items circulating within and between communities. These practices, Mauss argued, reveal that reciprocity and moral obligation are essential mechanisms in any society. Variations of the phenomenon across different cultural contexts reveal that exchange and service performed out of obligation are not diametrically opposed to exchange for money out of economic self-interest. Rather, these co-exist in different configurations and with fluid boundaries between them (Hart, 2014). Mauss's notion of reciprocity is taken up by James C. Scott (1976) in his book on the 'moral economy' of peasant societies. Scott (1976, p. 167) argued that the norms of reciprocity and the right to subsistence are fundamental to communities of smallholder farmers: 'The right to subsistence, in effect, defines the minimal needs that must be met for members of the community within the context of reciprocity.' In other words, what counts as an acceptable quality and quantity of (food) items necessary for survival is premised on the perceived legitimacy of the social interactions and transactions underlying subsistence.

We can deploy what, according to Mauss, are two constitutive elements of social formation-bodily techniques in social interaction, and exchange relations based on reciprocity - to develop a novel analysis of practices of resistance against the slavery system in the Americas. We can examine bodily social practices, other than plantation agriculture, through which social interaction became a source of revolt, escape, and resistance contesting the illegitimacy of the suppressive plantation regime. One option is to assume the alternative must be stored in the minds of the enslaved Africans as memories from the communities they once lived in. However, the nature of historical sources makes it impossible to provide evidence in favour (or against) this assumption. More likely, and supported by recent historiography, the alternative practices existed within and alongside the plantation system. The predominant activity of the slave-based plantation system in the Americas was the production of crops and products made from these crops for export to Europe. Cane fields and sugar factories dominated in most places, next to cotton, coffee, cocoa, and other products. Besides the export crop, plantations also had fields reserved for growing food. What crops were grown on these provision grounds was partly determined by plantation managers but with considerable options for slaves to add crops.

Some plantations differentiated between fields for provisions and fields for the slaves, the latter often containing a larger variety of food crops and medicinal plants. There were more spaces within and around the plantation that slaves used to provide for their food. These spaces enabled slaves to employ and cultivate their own techniques of farming, hunting, and fishing, following traditional practices from Africa or learned in social interaction in the plantation context. The same techniques also formed the basis of maroon communities (Van Andel et al., 2016). Marronage - forms of deflection varying from secretive escape to flight after revolt-became a viable option due to the knowledge and techniques of subsistence that slaves were able to develop in combination with working on the fields 
and in the factories of the plantations. Marronage was common in most New World areas where European colonisers set up slave-based plantation agriculture.

The options for slaves to spend time on provision grounds and other subsistence activities depended on the characteristics of the plantation, such as the ecology and landscape, the crop, the tasks, and the strictness of the regime. The shelter of swamps, hills, and dense forest made a move away from the plantation a worthwhile alternative and subsistence farming was the technique by which enslaved groups re-established a moral economy that changed the nature of plantation-based societies. In the Pará region of Brazil, this resulted in a parallel economy that occasionally dominated the plantation economy (De la Torre, 2018). In Haiti, subsistence farming and marronage formed a launchpad for the slave revolt of 1791 and continued as a source for resistance, a reason why subsequent governments of the free nation failed to sustain former estate models of agriculture (Gonzalez, 2019). In Suriname and most British plantation economies in the Caribbean, Asian contract labourers, like the enslaved Africans before them, also opted for subsistence. In many of these areas the smallholders of Asian origin became successful rice farmers and collectively transformed the rural economies (Maat and Van Andel, 2018).

\section{Case 2. Situated knowledges and skilled visions: Sheep scab notification practices in Scotland}

Sheep scab has a long history in Scotland, and until the late 1980s sheep scab numbers had been very low due to compulsory bi-yearly treatments observed by the local police, and notification legislation. However, when sheep scab was nearly eradicated the UK government decided that full eradication was not feasible or cost effective, and the policy of compulsory treatment changed in 1989, with the removal of sheep scab from the list of notifiable diseases in 1990. This led to major scab outbreaks in the early 1990s, with more than 3,000 sheep farms affected in the UK year-on-year (ADAS, 2008). The Scottish government decided to reissue sheep scab as a notifiable disease under the 2010 Sheep Scab Scotland Order and its 2011 amendments. This order means that in case of sheep scab suspicion, the disease has to be notified to the animal health authorities. In practice, however, notification is often avoided, or only done when sheep scab has become clearly visible. To understand why the renewed notification legislation for sheep scab is not being taken up by sheep farmers in the way envisioned by the Scottish government, we need to follow their local knowledge of sheep scab from below, and how this is premised on a social order based on 'preventing' disease outbreaks.

The concepts of situated knowledges and skilled visions are particularly helpful for understanding the practices of sheep farmers and veterinarians (not) to notify sheep scab at an early clinical stage. Donna Haraway (1988) coined the term 'situated knowledges' as an attempt towards 'a more adequate, richer, better account of a world, in order to live in it well and in critical, reflexive relation to our own 
as well as others' practices of domination and the unequal parts of privilege and oppression that make up all positions' (p. 579). For Haraway, rejecting the notion of objectivity as a 'view from nowhere, from above' (p. 589), knowledge is inevitably situated in time and space (also see Mol, 2002) and thus is inherently partial and never fully visible. The concept of skilled visions extends the concept to emphasise how visions and detached observation are not necessarily identifiable and should therefore not be opposed to other senses. Thus, skilled visions are 'embedded in multi-sensory practices' (Grasseni, 2007, p. 4). Methodologically, this means that in order to understand how farmers tackle sheep scab we need to attend closely to the diverse practices through which they recognise and act upon it, where seeing 'involves an on-going combination of recognising, acknowledging and acting upon' (Cohn, 2007, p. 94). Seeing, knowing, and practising are co-joined, and one cannot pre-empt the other. The practices performed in recognising and suspecting sheep scab combines multiple - though not only human-senses.

The social order of preventing sheep scab is rooted in the skilled visions of farmers to recognise and treat sheep scab at an early stage and in its situated knowledges that include a former history of near eradication through preventive bi-yearly treatments. First, to suspect sheep scab at an early stage is skilled work, because it is caused by scab mites that are invisible to the naked human eye. Their invisibility, and the possibility of having other ectoparasites that cause itchy sheep (such as lice, ticks, maggots, or keds) makes it skilled work to recognise sheep scab early on (Van den Broek and Huntley, 2003). Many farmers mentioned sweaty wool, hypersensitivity (biting or spasm when being touched), itchiness on their backs and sides (dirty scratch marks from hooves, clean marks from licking/biting the fleece), and crusty skin as early signs of sheep scab (Middelveld, 2019). These clinical signs clearly are about more than looking at sheep alone, including touching sheep (the texture of their skin), as well as about the sheep's response to being touched. Recognising sheep scab at an early stage is therefore an embodied practice, based on skilled visions and situated knowledges. Furthermore, sheep scab suspicion grows stronger when visible and tangible clinical signs add up (Mol, 2002).

Once sheep scab is suspected, many farmers and veterinarians prefer to treat scab as soon as possible to prevent it from spreading, instead of notifying the authorities (Middelveld, 2019). The focus on 'preventive' treatments at an early stage of the disease is rooted in its history of near eradication before the regulations changed. Many farmers and veterinarians mentioned that scab is easily prevented (Middelveld, 2019). Furthermore, the absence of sheep scab on a farm strengthens the good reputation of the farmer (Burton, 2004), because it indicates that their biosecurity practices are effective, whereas the (known) presence of sheep scab results in reputation damage to the farm, resulting in low prices for their sheep. For these reasons, Patrick, a veterinarian, mentioned he prefers not to notify sheep scab when he encounters it:

[W] don't want to make it a notifiable outbreak. We want the farmer to be able to treat it, and [to] be on top of it before anybody realises that he's got 
scab [...] Because of that quite often we diagnose what would be, it may be scab rather than it is scab. And treat in case of, rather than because of [...] It's because the farmers feel that it's an awful stigma to actually have them report it to the government because they have scab [...] If you can step in quickly it means that it's contained within one farm rather than spread to neighbours.

Notification is also not preferred because of the paperwork hassle, and to avoid government interference at the farm (Middelveld, 2019). The visit of ministry veterinarians at the farm also alerts neighbours that there is a problem with livestock from the visited farm. Notification is thus considered necessary only in case of a clearly visible outbreak of sheep scab, whereas sheep scab in an early stage should be treated as soon as possible. Mark, a farmer, explained that he would only notify clinically visible sheep scab as follows: 'Well, we've never actually experienced it, because we've never got to that stage. We recognised it and cured it before we needed the Department.' Thus, a notification is issued only when sheep scab is identified at a late clinically visible stage. If it is recognised and treated before that stage, it is not considered an outbreak in need of notification, but a disease that warrants preventive treatment instead. This means that identification practices at the clinical stage of sheep scab shapes the boundaries for notification.

This case clearly shows that farmers' and veterinarians' situated knowledges and skilled visions of sheep scab are based on their experience with and knowhow of the disease, which is embedded in recognition and notification practices. These local knowledges and practices conflict with assumptions embedded in legislation which not only have reissued sheep scab as a notifiable disease but which rely on farmers and veterinarians notifying authorities of sheep scab suspicion at an early stage of the disease, which are then used by the Scottish government to monitor the disease. However, it is clear that these numbers are inherently flawed, because the notification of the disease by local farmers and veterinarians is often only executed at a late clinical stage of the disease and only when early-stage treatment has been unsuccessful. The mismatch between notification practices based on skilled visions of sheep scab 'from below' and the vision of the government to use notification numbers to monitor the disease 'from above' is paramount and has an important implication for sheep scab governance. By not taking sheep scab knowledges and practices 'from below' seriously (English et al., 1992; Lavau, 2017), policymakers are overlooking valuable alternative ways of coping with sheep scab in practice (Hinchliffe et al., 2017).

\section{Case 3. Public engagement with GM foods}

Agricultural biotechnology is commonly presented as part of the solution to the grand challenge of global food security. With rising world populations, persistent hunger, and a growing demand for food globally, it is unsurprising that food security is one of this century's most critical challenges for global 
policymaking. A current and dominant policy narrative is the 'sustainable intensification of global agriculture' frame (Royal Society, 2009), which presents novel science and technology as having a primary role to play in meeting these challenges. Without radical advances, particularly at the molecular levelthe argument runs-it is hard to imagine how yields can be increased without adverse environmental impact or the cultivation of new land. Novel science and technology have, at least within this epistemic framework, the potential to contribute to food production through forms of genetic improvement, including genetically modified (GM) crops that have been altered to introduce new and desirable traits.

While the global imperative for the genetic modification of crops and foods is often made by policymakers and establishment scientific communities, it is less clear how dominant science policy framings map onto public opinion. While institutions such as the Royal Society $(2015$, p. 1) may feel entitled to say that 'the science demonstrates that these [GM] techniques are not inherently any more risky than conventional breeding approaches used to produce crops,' that 'robust regulatory processes [are] in place to assess the safety of GM crops and approve those that can be used for cultivation, food and feed,' and that by implication the key task for policymakers and science policy organisations is to ensure that 'the science around the production of GM food and feed needs to be better communicated so that people are able to feel informed,' this does not exhaust the science policy framing. What if there are alternative ways to frame the science policy debate that speak more directly to the ways that people feel and think about GMOs from the bottom up; or that address actual and latent public concerns and that recognise the 'reasonableness' of public apprehension and ambivalence? Such a frame contrasts starkly to the still prominent policy narrative where public opinion (typically viewed as overly negative) is represented as a problem that needs to be addressed, classically through the provision of one-way communication flows rather than as the holders of legitimate views and concerns that need to be engaged with through dialogue.

It was this ambition to scrutinise and hold to account this dominant science policy configuration that structured an early piece of public engagement research conducted in 1996/1997 in the UK, the Uncertain World study (Grove-White et al., 1997). Importantly, this study pre-dated the public controversy over GM crops and foods that came to prominence in the UK and mainland Europe in 1998/1999. The study sought to cast light on how people feel about agricultural genetic modification technology in the UK, to explore possible future public reactions and responses, and to offer suggestions for improved institutional handling of the technology. The study rested on the interpretation of nine focus group discussions, involving a selection of population groups in the north and south of England, covering a spectrum of social classes and age groups, with a bias towards women. The research was designed to develop clues about factors shaping public attitudes and likely responses in a field where few at the time could be claimed to have 'informed' or 'settled' views. 
Given this unfamiliarity, the discussions began with a contextual discussion (see Chapter 12, this volume, on the importance of context in public deliberations on emerging technology) on what had changed in the world of food over the last five to ten years or so, exploring with participants what had been lost and gained. How people will respond to genetically modified (GM) foods, the argument went, depends on how they think about food in general and what they consider to be the issues surrounding the role and application of technology in food production. The discussions themselves were illuminating, as participants spoke of their ambivalence towards the use of advanced technology in food: while technology had enabled people to lead busy and convenient lives, it had also generated concerns about food processing, the use of artificial preservatives, and the apparent increase in food health scares. Drawing on the then proximate 'mad cow' disease controversy, participants expressed unease about the integrity and adequacy of government regulations, about official 'scientific' assurances of safety, about the benign intentions of food producers and processors, and about the increasing perceived 'unnaturalness' of food. Such early discussions provided clues to the ways in which public responses to GM foods would later be configured, highlighting the salience of concepts of trust, naturalness, justification, and perceived agency in moderating public responses. Subsequently, different frames on GMOs were introduced, making clear distinctions between current and proposed uses of genetic modification techniques, highlighting the potential for the transgenesis of different genes (both plant and animal) in different contexts of application, from food production to animal rearing to medical uses.

The study produced a distinctive set of findings. It reported people's considerable ambivalence towards the prospect of GM foods, a profound sense of inevitability and fatalism that the technology would become pervasive in food production despite public concern, and the apparent paradox that while people may purchase GM foods they may also harbour significant unease about the technology as a whole and about the potential implications of its trajectories. In addition, the study found that people had concerns about the integrity and adequacy of present patterns of government regulation, and in particular about official 'scientific' assurances of safety that reflected at the time wider issues of trust in UK political institutions. While these findings were not wholly novel at the time-other public opinion research had similarly identified latent public concern-what was novel was the interpretation of these findings as offering a critique to established GMO policy and regulatory frameworks which had tended to view public concerns as irrational and as best ameliorated through scientifically robust information (e.g. on harms). This 'deficit' understanding of the public had been critiqued in previous scholarship by one of the authors of the study, Brian Wynne, and this critique underpinned both the conceptual frame of the research and the interpretation of its findings (Wynne, 1992).

In the Uncertain World report, the authors sought to articulate the sense of open-ended uncertainty evoked by public deliberation on the technology, and 
the strong feelings of impotence and fatalism this seemed to engender. In such circumstances, unambiguous unilateral assertions by industry and government spokesmen that the technology can and should be managed safely on a 'case-bycase' basis was presented as likely to have the effect of compounding, rather than assuaging, the mistrust felt by individuals across all population groups. Thus, notwithstanding differences in participants' responses, it was the convergences in public talk and their contrast with official discourses and understandings that drove the analysis of the data and their interpretation. Indeed, when the GM food and crop controversy unfolded in the UK and Europe in 1998/1999, and when the then UK government chief scientific adviser (GCSA) was exposed to the Uncertain World study, he responded in a personal communication as follows, speaking to the potential political salience of this anticipatory mode of focus group research on public perceptions:

I now have had a chance to read 'Uncertain World,' which I wish I had indeed read earlier. It is in many ways a remarkably prescient document.

(May 1999)

\section{Conclusion}

What lessons can we draw from the three cases above? A key lesson from the first case-involving the history of slave revolt and marronage as rooted in alternative agricultural practices-lies in the persistence and recurrence of similar forms of challenge and contestation to the predominant social order of plantation economies. The long-lasting suppression by subsequent colonial regimes aimed at exploitation of labourers was continuously challenged by the moral economy of subsistence out of which alternative social orderings emerged. The enslaved Africans, Maroons, and, after abolition, many Asian contract labourers all cherished the limited options to grow their own food and spend time in the fields the way they wanted. Escape, through marronage and illicit networks within and between plantations, allowed a gradual expansion of these practices to the extent to which they gradually overturned the plantation system. The specific historical setting of a ruling colonial class versus an exploited and suppressed labour force that nevertheless persisted in pursuing an alternative social order may suggest that knowledge from below flourishes under conditions of extreme adversity, or may require antagonistic divides between minority elites and an impoverished rural population. The second case challenges such interpretations.

In this case, we see how the sheep scab outbreaks triggered the Scottish government to devise policy measures and regulations that not only ignored the knowledge of sheep farmers, but also existing ways of incorporating official health requirements within their practices through collaboration with local veterinarians. Local sheep farmers and veterinarians joined hands in early treatment of sheep scab to prevent it from spreading, but also to prevent government 
authorities from taking over, thereby losing control over their herds and farms. The case thus highlights the role of proactive intervention as a significant mechanism and feature of knowledge from below. The case also makes clear that knowledge from below and 'action from below' are mutually reinforcing. The values that triggered the need for early treatment enhanced local knowledge of sheep bodies and sheep behaviour, as much as the other way around.

Finally, in the third case it is the anticipation and probing of future consequences that is central, and how such anticipation can be produced through deliberation. The case of introducing genetically modified (GM) crops revealed the partiality of institutional views on what constitutes desirable innovation, including assumptions about how the general public would perceive such innovations in real world circumstances. The limitations of in-built norms and assumptions came to light after engaging with the wider public through a series of focus group meetings. What stands out from the case is that the complexity of the advanced scientific and regulatory knowledge that underpins GM crops appeared not to obstruct the 'lay' public from identifying and critiquing the specific values and interests deeply embedded in the development of GM crops, including the articulation of concerns over their limitations and the sketching of alternatives. Moreover, in the public deliberation, both science-based GM applications and alternatives are projected on a (nearby) future, highlighting the potential and importance of addressing such issues in an anticipatory manner before applications are realised.

In assorted ways, summarised in Table 2.1, these contributions configure knowledge as a plural concept that is built out of scientific, institutional, practical, and local practices, and where a failure of alignment can lead to contestation. In each case the knowledges from below were resistant to, and unrecognised by, dominant epistemologies of knowledge production and their associated governing social orderings. It is important therefore to take knowledge from below seriously; both because it provides valuable alternatives and for how it opens up

TABLE 2.1 Connectivity and the making of legitimacy

\begin{tabular}{|c|c|c|}
\hline Cases & Epistemic and social connections & $\begin{array}{l}\text { Making knowledge from } \\
\text { below legitimate }\end{array}$ \\
\hline $\begin{array}{l}\text { Destabilising the } \\
\text { plantation } \\
\text { economy. }\end{array}$ & $\begin{array}{l}\text { Antagonistic and suppressive, } \\
\text { leading to resistance and escape, } \\
\text { eventually gaining recognition and } \\
\text { rapprochement. }\end{array}$ & $\begin{array}{l}\text { Through historical } \\
\text { analysis. }\end{array}$ \\
\hline $\begin{array}{l}\text { Sheep scab } \\
\text { notification } \\
\text { practices. }\end{array}$ & $\begin{array}{l}\text { Parallel and disconnected, local } \\
\text { coalitions between lay and expert } \\
\text { knowledge challenging 'top-down' } \\
\text { science-based policies. }\end{array}$ & $\begin{array}{l}\text { Through stakeholder } \\
\text { analysis and } \\
\text { participatory } \\
\text { observation. }\end{array}$ \\
\hline $\begin{array}{l}\text { Public engagement } \\
\text { with GM foods. }\end{array}$ & $\begin{array}{l}\text { Multiple and disconnected, causing } \\
\text { suspicion and alienation from } \\
\text { formal (scientific) institutions. }\end{array}$ & $\begin{array}{l}\text { Through stakeholder } \\
\text { analysis and public } \\
\text { engagement. }\end{array}$ \\
\hline
\end{tabular}


the possibility of doing things (agriculture, sheep scab, or GM) differently. These findings - both epistemic and practical—raise implications for governance and inclusive development for which this chapter provides a set of solid insights.

\section{Note}

1 This paragraph is based on Schlanger (2006).

\section{References}

ADAS (2008). An evidence base for new legislation and guidance for implementation of a compulsory treatment period for sheep scab. Accessed 18 June 2020. https://www.webarchive. org.uk/wayback/archive/20170701074158/http://www.gov.scot/Publications/ 2008/07/17113358/51

Burton, R. (2004). Seeing through the 'good farmer's' eyes: Towards developing an understanding of the social symbolic value of 'productivist' behaviour. Sociologia Ruralis, 44(2), 195-215.

Carenzo, S. (2020). Contesting informality through innovation 'from below': Epistemic and political challenges in a waste pickers cooperative from Buenos Aires (Argentina), Tapuya: Latin American. Science, Technology and Society, 3(1), 441-471.

Cohn, S. (2007). Seeing and drawing: The role of play in medical imaging. In: C. Grasseni (ed.). Skilled visions: Between apprenticeship and standards. New York: Berghahn Books, 91-105.

De la Torre, O. (2018). The people of the river: Nature and identity in Black Amazonia, 1835-1945. Chapel Hill: University of North Carolina Press.

Eltis, D. and Richardson, D. (2010). Atlas of the transatlantic slave trade. Yale: Yale University Press.

English, P., Burgess, G., Segundo, R. and Dunn, J. H. (1992). Stockmanship: Improving the care of the pig and other livestock. Ipswich: Farming Press.

Gonzalez, J. (2019). Maroon nation: A history of revolutionary Haiti. Yale: Yale University Press.

Grasseni, C. (ed.) (2007). Skilled visions: Between apprenticeship and standards. New York: Berghahn Books.

Grove-White, R., Macnaghten, P., Mayer, S. and Wynne, B. (1997). Uncertain world: GMOs, food and public attitudes in Britain. CSEC and Unilever.

Haraway, D. (1988). Situated knowledges: The science question in feminism and the privilege of partial perspective. Feminist Studies, 14(3), 575-599.

Hart, K. (2014). Marcel Mauss' economic vision, 1920-1925: Anthropology, politics, journalism. Journal of Classical Sociology, 14(1), 34-44.

Hinchliffe, S., Bingham, N., Allen, J. and Carter, S. (2017). Pathological lives: Disease, space and biopolitics. Chichester: Wiley Blackwell.

Jasanoff, S. (ed.) (2004). States of knowledge: The co-production of science and the social order. London: Routledge.

Jasanoff, S. and Simmet, H. (2017). No funeral bells: Public reason in a 'post-truth' world. Social Studies of Science, 47(5), 751-770.

Lavau, S. (2017). Public policy and calculative practices of risk: Making matters of concern and 'non-communicable' threats, from farm to fork. Sociologia Ruralis, 57(1), 23-40. 
Maat, H. and van Andel, T. R. (2018). The history of the rice gene pool in Suriname: Circulations of rice and people from the eighteenth century until late twentieth century. Historia Agraria. Revista de Agricultura e Historia Rural, 75, 69-91.

Macnaghten, P. (2021). Towards an anticipatory public engagement methodology: deliberative experiments in the assembly of possible worlds using focus groups. Qualitative Research. 21(1), 3-19.

Mauss, M. (1923/2000). The gift: forms and functions of exchange in archaic societies. W.W. Norton.

May, R. (1999). Personal communication to Robin Grove-White. Unpublished manuscript.

Middelveld, S. (2019). Sheep scab in Scotland: An exploration of multiple disease situations. Unpublished PhD dissertation. University of Aberdeen.

Mol, A. (2002). The body multiple: Ontology in medical practice. Duke University Press.

Royal Society (2009). Reaping the benefits: Science and the sustainable intensification of global agriculture. Assessed 17 June 2020. https://royalsociety.org/topics-policy/publications /2009/reaping-benefits/

Royal Society (2015). Response to the Food Standards Agency call for views on the European Commission proposal on GM food and feed. Assessed 17 June 2020. https://royalsociety .org/ /media/policy/Publications/2015/28-10-15-food-standards-agency-GM-foo d-and-feed.pdf

Rose, N. (2006). The politics of life itself: Biomedicine, power, and subjectivity in the twenty-first century. Princeton: Princeton University Press.

Ross, C. (2014). The plantation paradigm: Colonial agronomy, African farmers, and the global cocoa boom, 1870s-1940s. Journal of Global History, 9(1), 49-71.

Schlanger, N. (2006). Marcel Mauss; Techniques, technology and civilisation. New York: Durkheim Press/Berghahn Books.

Scott, J. (1976). The moral economy of the peasant: Rebellion and subsistence in Southeast Asia. Yale: Yale University Press.

Stirling, A. (2008). 'Opening up' and 'closing down': Power, participation, and pluralism in the social appraisal of technology. Science Technology \& Human Values, 33(2), 262-294.

Tsing, A. (2015). The mushrooom at the end of the world: On the possibility of life in capitalist ruins. Princeton: Princeton University Press.

Van Andel, T., Meyer, R., Aflitos, S. et al. (2016). Tracing ancestor rice of Suriname Maroons back to its African origin. Nature Plants, 2(10), 16149.

Van den Broek, A. and Huntley, J. (2003). Sheep scab: The disease, pathogenesis and control. Journal of Comparative Pathology, 128(2/3), 79-91.

Wynne, B. (1992). Misunderstood misunderstanding: Social identities and the public uptake of science. Public Understanding of Science, 1(3), 281-304. 